\title{
The fish fauna of Gilbert Bay, Labrador: a marine protected area in the Canadian subarctic coastal zone
}

\author{
Joseph S. Wroblewski*s ${ }^{*}$ Leanne K. Kryger-Hann ${ }^{\dagger}$, David A. Methven ${ }^{\ddagger}$ and Richard L. Haedrich ${ }^{\dagger}$ \\ *Ocean Sciences Centre, Memorial University of Newfoundland, St John's, Newfoundland and Labrador, Canada, A1C 5 S7. \\ ${ }^{\dagger}$ Department of Biology, Memorial University of Newfoundland, St John's, Newfoundland and Labrador, Canada, A1B 3 X9. \\ †Department of Biology and Canadian Rivers Institute, University of New Brunswick, Saint John, New Brunswick, \\ Canada, E2L 4L5. sCorresponding author, e-mail: jwroblew@mun.ca
}

\begin{abstract}
The Marine Protected Area in Gilbert Bay, Labrador is the first established in the subarctic coastal zone of eastern Canada. A standardized survey of the fish fauna of Gilbert Bay was initiated during the ice-free season of 2004 to provide baseline information on the fish present in water less than $15 \mathrm{~m}$ deep. Beach seines and gill-nets sampled three management zones within the bay which are afforded different levels of protection from human activity. The 25 species in 15 families recorded belong to five ecological guilds: (1) estuarine and marine fish resident in the bay; (2) anadromous species transiting the bay; (3) marine species which migrate into the bay to spawn; (4) offshore-spawning marine fish for which the bay is a nursery area; and (5) marine species which occasionally migrate into the bay to feed. Gilbert Bay lies in a transition zone between Arctic and coldtemperate biogeographical provinces, and its fish fauna is dissimilar from a cold-temperate fish assemblage described for Trinity Bay in eastern Newfoundland.
\end{abstract}

\section{INTRODUCTION}

The global decline in abundance of commerciallyimportant marine fish has underscored the need for conserving living marine resources (Worm et al., 2006). Many coastal nations have declared fishery conservation zones, yet on a global scale only $0.01 \%$ of the ocean is currently protected from human activity (Pauly et al., 2002). The majority of marine protected areas (MPAs) are located in tropical and warm-temperate waters (Roberts \& Hawkins, 2000). Relatively few protected areas have been established in boreal regions.

In Canada, MPAs are established under the Oceans Act of January 1997 (Bill C-26, Section 35 (1)) to conserve commercial species and protect non-commercial species, including marine mammals. Protection is afforded to endangered or threatened marine species and their habitats, unique habitats, and marine areas of high biodiversity or biological productivity (Jamieson \& Levings, 2001).

Gilbert Bay, an inlet located on the south-east coast of Labrador, was announced by the Minister of Fisheries and Oceans Canada in 2005 as the first MPA in eastern Canada's subarctic coastal zone established and managed under the Oceans Act. The bay has its own management plan, developed jointly by local community leaders, marine resource users, researchers from Memorial University of Newfoundland, and representatives of the Canada Department of Fisheries and Oceans (DFO). The Gilbert Bay MPA is not a harvest refugium or 'no-take reserve' (Hilborn et al., 2004). Aboriginal fisheries for Salmo salar Linnaeus,
1758 Atlantic salmon and Salvelinus alpinus (Linnaeus, 1758) Arctic char using gill nets are allowed in some regions of the bay, but landings are restricted to personal consumption. The primary objective of the Gilbert Bay MPA is to protect its resident population of Gadus morhua Linnaeus, 1758 Atlantic cod (Green \& Wroblewski, 2000; Morris \& Green, 2002). These cod have a reddish or golden-brown colour due to their carotenoid-rich diet of invertebrates (Gosse \& Wroblewski, 2004; Wroblewski et al., 2005). The Gilbert Bay cod population is genetically distinguishable from coastal cod of eastern Newfoundland and from offshore cod of the Grand Banks (Ruzzante et al., 2000; Beachem et al., 2002). Gilbert Bay cod are a subpopulation of the northern cod metapopulation (Smedbol \& Wroblewski, 2002). The northern cod was declared 'Endangered' by the Committee on the Status of Endangered Wildlife in Canada (COSEWIC, 2003), but has yet to be protected by Canada's Species at Risk Act. A rebuilding of the Gilbert Bay cod subpopulation will help protect the diversity of the northern cod metapopulation (Smedbol \& Stephenson, 2001).

To date, management planning for the MPA has focused on the 'golden cod of Gilbert Bay', since there exists biological data (Green \& Wroblewski, 2000; Morris \& Green, 2002) on which to base management decisions. However, the management plan is founded on a broader ecosystem approach, and scientific information on other species which inhabit Gilbert Bay is required.

Standardized sampling to determine the fish fauna had not been conducted in Gilbert Bay prior to our research. General information on the north-west Atlantic fish fauna 


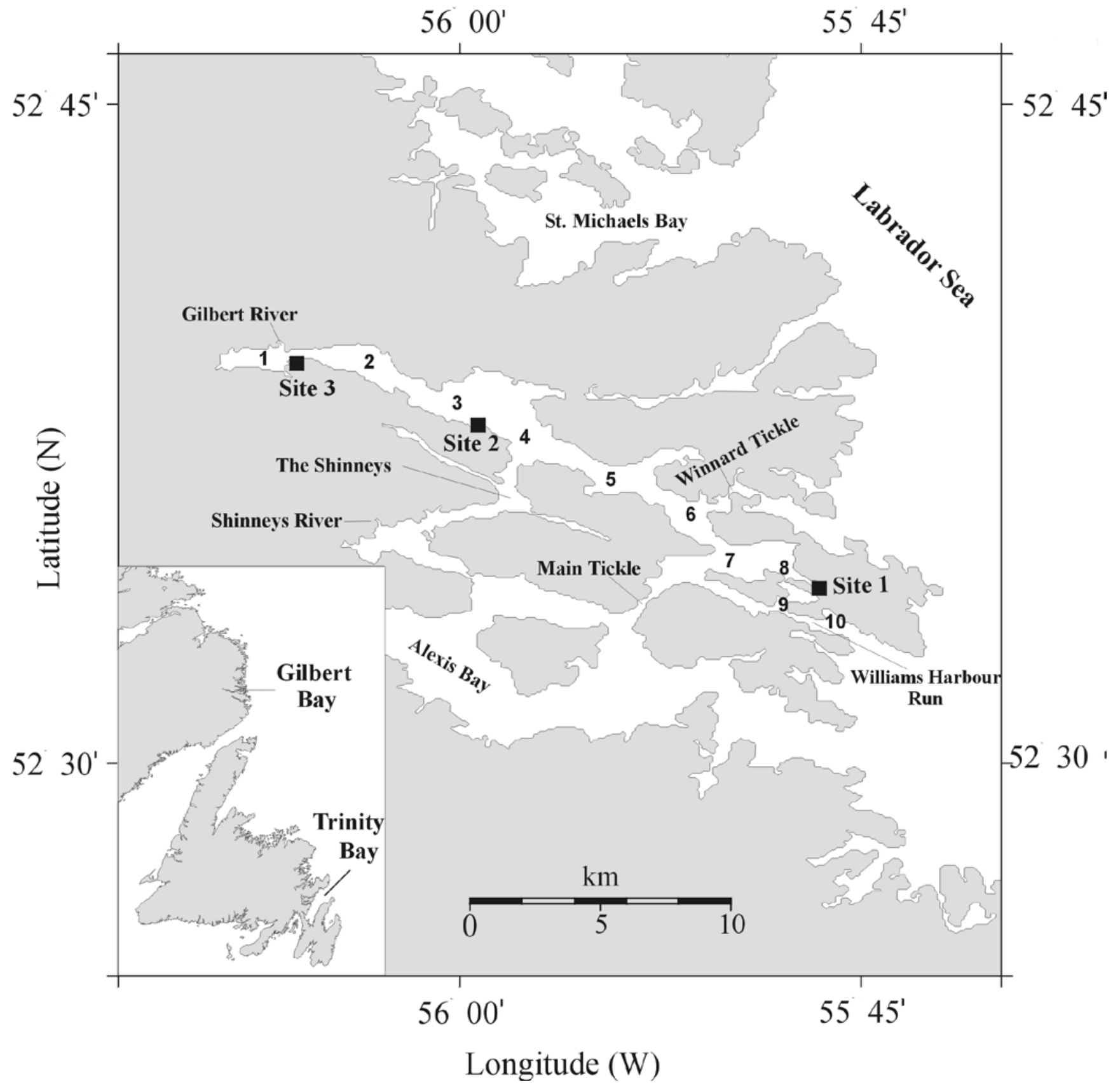

Figure 1. Map of Gilbert Bay, Labrador showing place names mentioned in the text and location of standard sampling Sites 1, 2 and 3. Hydrographic station locations of 23 August 2004 temperature and salinity profiles along the main axis of the bay are numbered 1-10.

is available (Scott \& Crossman, 1973; Scott \& Scott, 1988; Collette \& Klein-MacPhee, 2002), but there have been few studies of the fish in the bays, inlets and arms of the Labrador coastline. First studies of Labrador coastal fish are summarized by Backus (1957) who lists fish collected between Forteau Bay in the Strait of Belle Isle and Kangalaksiorvik Fjord (mouth latitude $59^{\circ} 25^{\prime} \mathrm{N}$, longitude $63^{\circ} 03^{\prime} \mathrm{W}$ ). Most of these fish were collected during the 'Blue Dolphin' Labrador Expeditions of 1949, 1950 and 1951. Marine collections were made with beam and otter trawls near the headlands. Freshwater collections were made with seines and gill-nets primarily in the St Mary's River (mouth latitude $52^{\circ} 18^{\prime} \mathrm{N}$, longitude $55^{\circ} 50^{\prime} \mathrm{W}$ ) and in the lower tributaries of the Hamilton Inlet-Lake Melville estuary. There is no mention in Backus (1957) of collections in Gilbert Bay or at its mouth (latitude $52^{\circ} 32^{\prime} \mathrm{N}$, longitude $\left.55^{\circ} 43^{\prime} \mathrm{W}\right)$. Commercial fish stock abundance surveys by DFO have provided information on species assemblages on the Newfoundland and Labrador continental shelf (Gomes et al., 1995), but these bottom-trawl surveys do not sample rough seabed along the coastline.

Here we report on the fish fauna collected in Gilbert Bay during the ice-free season of June-October 2004 along with the prevailing oceanographic conditions. Additional collections were made in August 2005. Comparison of these data with future surveys is one component of a monitoring programme planned for the MPA.

Stonehouse (1989) suggests the south-east coast of Labrador lies within a subarctic zone separating polar from temperate regions. Biogeographic studies by Steele (1983) 


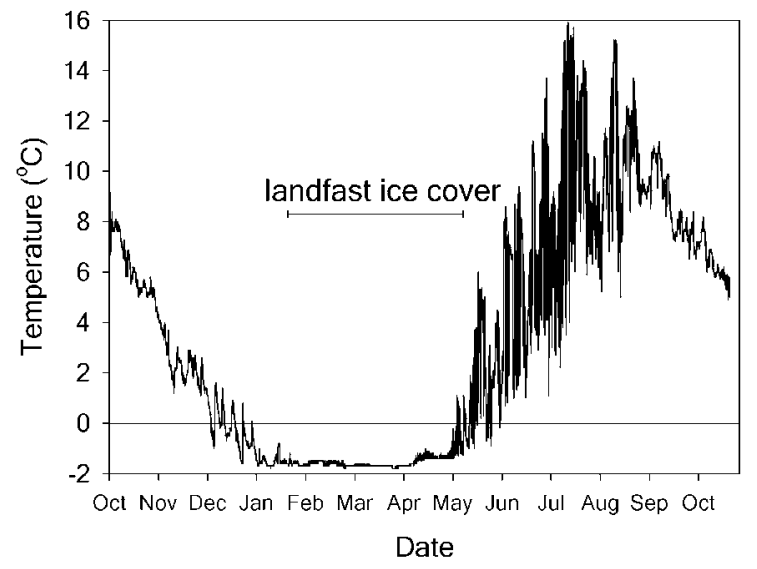

Figure 2. Seawater temperature at $4 \mathrm{~m}$ depth at Site 1 recorded between 3 October 2003 and 27 October 2004.

identified the Strait of Belle Isle as the oceanographic boundary separating subarctic waters of Labrador from cold-temperate coastal waters of Newfoundland. Given the location, we hypothesized that the fish fauna of Gilbert Bay would be a combination of arctic fish at their southern range limit and temperate fish near their northern range limit. If this is correct, the fish fauna would be different from the fish assemblage sampled in a similar manner by Methven et al. (2001) in cold-temperate Trinity Bay, Newfoundland at Bellevue (latitude $47^{\circ} 38^{\prime} \mathrm{N}$, longitude $53^{\circ} 43^{\prime} \mathrm{W}$ ).

\section{MATERIALS AND METHODS}

Gilbert Bay is $25 \mathrm{~km}$ long and 1-3 km wide, with a surface area of approximately $60 \mathrm{~km}^{2}$ (Figure 1 ). The bay has the geographical features of a shallow fjord and estuary. The Gilbert River and Shinneys River flow into Gilbert Bay. The upper portion of the bay is generally shallower than 20 $\mathrm{m}$, but depths in the outer bay approach $80 \mathrm{~m}$. The shore of exposed bedrock was shaped by glaciers 11,000-14,000 years ago (Clark \& Fitzhugh, 1992). Narrow beaches of cobble, pebbles and course sand occur at several locations in the bay. Glacial retreat has left boulders scattered along the shoreline.

Gilbert Bay is joined to the Labrador Sea by two passages, Winnard Tickle and Williams Harbour Run (Figure 1). Main Tickle connects Gilbert Bay to neighbouring Alexis Bay. The southward flowing Labrador Current governs the oceanographic conditions of the outer bay (Colbourne et al., 2005). Landfast ice completely covers the bay for approximately five months of the year, usually from midDecember until mid-May (Green \& Wroblewski, 2000; Morris \& Green, 2002).

\section{Sampling sites}

Net sampling of shallow waters of the bay was conducted during the ice-free months of 2004 (Figure 2). Sampling began in early June and ended in late October when ice formation began along the shoreline. Sampling was conducted on five consecutive days per month during June, July, August and October.

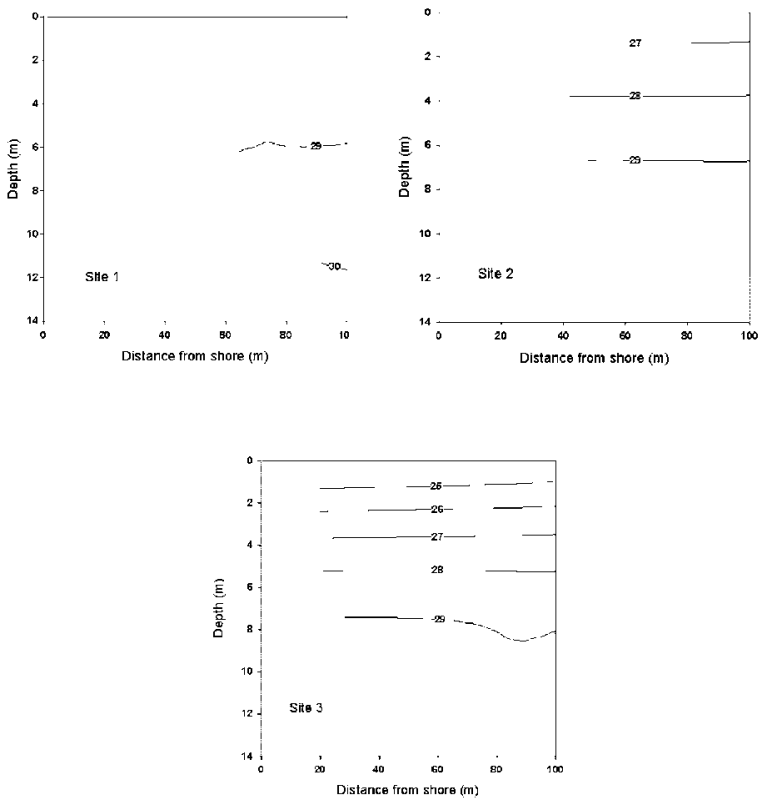

Figure 3. Seawater salinity (\%o) sections at Sites 1, 2 and 3 measured on 23 August 2004.

Three standard sampling sites were chosen. The location of each site was based on the presence of a beach which could be seined. Site 1 is near the headlands of the bay, Site 2 is in the central region of the bay, and Site 3 is located within the inner bay (Figure 1). By design, a standard sampling site occurs in each of the three management zones of the MPA (www.gilbertbay.com/plan.htm).

The beach at Site 1 measures $174 \mathrm{~m}$ along the shoreline at high tide. The slope of the subtidal zone (Figure 3) was determined by depth soundings with $10 \mathrm{~m}$ spacing from the shoreline using a metered rope. There is a rocky bar $45 \mathrm{~m}$ seaward from the high tide mark. Freshwater runoff flows onto the beach through a culvert connected to a pond. A sample of beach substrate taken at Site 1 consisted of $47 \%$ pebbles (4-64 mm diameter), $20 \%$ granules $(2-4 \mathrm{~mm}$ diameter) and 33\% sand (0.0625-2 mm diameter) when separated using a Humbolt Mfg. Co ${ }^{\circledR}$ mechanical shaker and classified according to the Wentworth grain size scale (Shepard, 1963).

The beach shoreline at Site 2 is $83 \mathrm{~m}$ long at high tide. The subtidal zone (Figure 3) drops off sharply $30 \mathrm{~m}$ from the shoreline. A sample of beach substrate taken from Site 2 was $92 \%$ pebbles, $5 \%$ granules and $3 \%$ sand. The beach shoreline at Site 3 is $72 \mathrm{~m}$ in length. The subtidal zone has a steep slope (Figure 3). A sample of beach substrate at Site 3 was composed of $27 \%$ pebbles, $30 \%$ granules and $43 \%$ sand.

\section{Oceanographic data collection}

A VEMCO $^{\circledR}$ temperature data logger was deployed at Site 1 to monitor seawater temperature during the winter prior to the study, and also during the sampling period. The logger was positioned $3 \mathrm{~m}$ off the bottom, $4 \mathrm{~m}$ below the surface. The logger recorded seawater temperatures hourly for 389 days, from 3 October 2003 to 27 October 2004 (Figure 2). Temperature and salinity profiles taken within $100 \mathrm{~m}$ from 
A

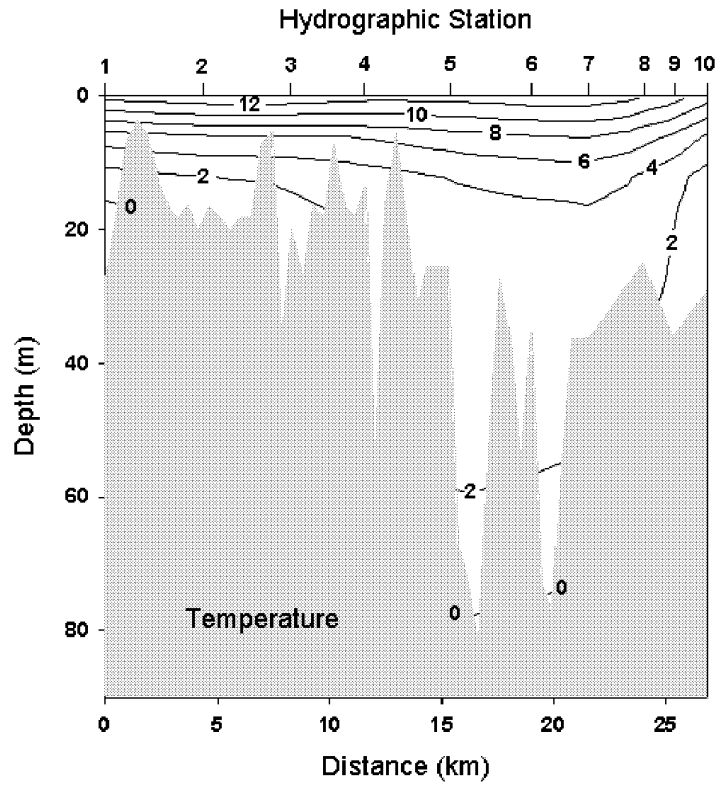

B

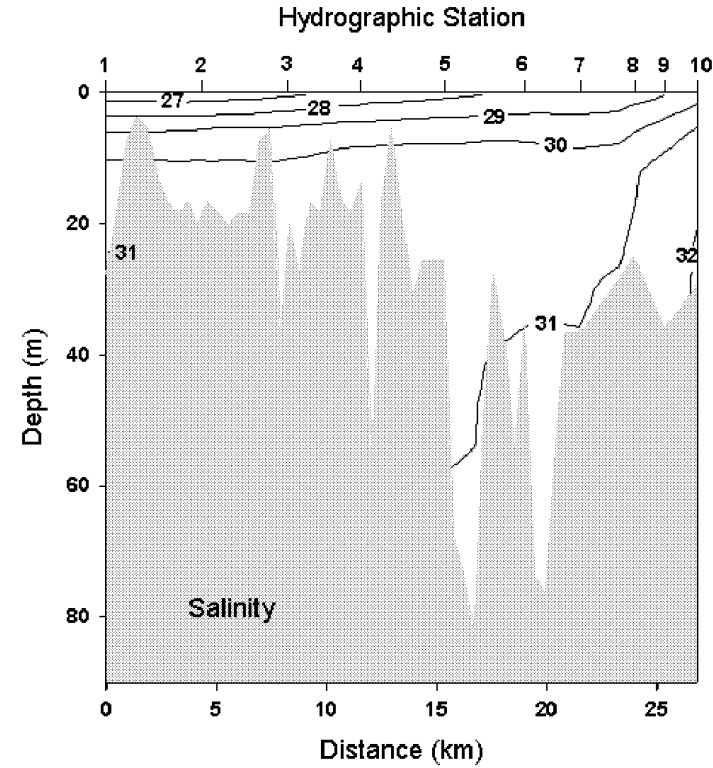

Figure 4. (A) Seawater temperature $\left({ }^{\circ} \mathrm{C}\right)$ section and (B) salinity (\%) section along the main axis of Gilbert Bay measured on 23 August 2004. Positions of hydrographic CTD Stations 1-10 are shown in Figure 1.

the shoreline were made at Site 1, Site 2 and Site 3 using a $\mathrm{YSI}^{\circledR}$ Model 30 water quality probe in August (Figure 3 ) and October 2004. A Seabird ${ }^{\circledR}$ Electronics Inc. CTD was used to record profiles of temperature and salinity along the main axis of Gilbert Bay in August 2004 (Figure 4).

\section{Methods of collecting fish}

A $10 \mathrm{~m}$ beach seine, $25 \mathrm{~m}$ beach seine and gill-nets of various mesh sizes were used to collect specimens at Sites 1, 2 and 3. Beach seining was performed under various tidal and sea state conditions. At each sampling site the smaller beach seine $(10 \mathrm{~m}$ by $1.5 \mathrm{~m}$ panel, with $10 \mathrm{~mm}$ stretch mesh netting) was hauled parallel to the shoreline by two people wearing chest waders to sample water $<1.5 \mathrm{~m}$ deep. The beach was sectioned to allow continuous seining between rock obstacles. The tow time was 1-2 minutes, depending on the sectioned length of the beach. Sampling with the 10 $\mathrm{m}$ beach seine was conducted during both day and night at Site 1. At Site 2 and Site 3 sampling with the $10 \mathrm{~m}$ beach seine was logistically restricted to daytime.

At each sampling site the larger beach seine $(25 \mathrm{~m}$ by $1.5 \mathrm{~m}$ in the wing, with $10 \mathrm{~mm}$ stretch mesh netting throughout, and a $5 \mathrm{~mm}$ stretch mesh in the cod end) was used perpendicular to the shoreline to sample water 0-15 m deep. Depending on the slope of the subtidal zone at the site (Figure 3), the seine was deployed 30-50 $\mathrm{m}$ from the shoreline from a $6 \mathrm{~m}$ speedboat. Two people then pulled the net along the bottom onto the beach by hauling on ropes attached to bridles at the ends of the seine. Beach seining with the $25 \mathrm{~m}$ seine was logistically restricted to daytime at all three sites.

Gill-nets were used to collect fish at 3-15 m depth off the beach at each site. Gill-nets were set during the day, fished overnight, and retrieved the following day. In June all sites were fished with $50 \mathrm{~m}$ by $2.4 \mathrm{~m}$ panel monofilament gillnets. The gill-net deployed at Site 1 had a $1.3 \mathrm{~cm}$ stretch mesh. The gill-net deployed at Site 2 had a $2.4 \mathrm{~cm}$ stretch mesh. The gill-net at Site 3 had a $3.8 \mathrm{~cm}$ stretch mesh. In July, August and October collections at each site were made using $30 \mathrm{~m}$ by $3.7 \mathrm{~m}$ panel gill-nets made of nylon twine with a $7.6 \mathrm{~cm}$ stretch mesh.

Non-standard (i.e. exploratory) sampling was conducted using a $91.5 \mathrm{~m}$ by $2.4 \mathrm{~m}$ panel monofilament gill-net with $14 \mathrm{~cm}$ stretch mesh, set near the headlands of Williams Harbour Run (Figure 1). In the shallow ( $<5 \mathrm{~m}$ depth) arms of the central region known as The Shinneys (Figure 1), non-standard sampling used angling rod and lure.

Species were identified, counted and measured for standard length (SL) to the nearest millimetre. Representative specimens of all species collected (except the single Acipenser oxyrinchus oxyrinchus Mitchill, 1814 Atlantic sturgeon which was released) have been preserved and archived at the Provincial Museum of Newfoundland and Labrador in St John's. Specimens of juvenile Urophycis tenuis were deposited at the New Brunswick Museum in Saint John (NBM- 002171 and NBM- 002172).

\section{Analyses of fauna collections}

The Jaccard coefficient (Omori \& Ikeda, 1984) was used to determine the similarity among collections made at each site with the $10 \mathrm{~m}$ and $25 \mathrm{~m}$ seines. Gill-net collections were not included in the analyses due to inconsistency in mesh size of the nets deployed. The Jaccard coefficient $\left(\mathrm{S}_{\mathrm{J}}\right)$ is based on presence and absence of species in sample pairs:

$\mathrm{S}_{\mathrm{J}}=a /(a+b+c)$

where $a$ is the number of species present in sample $\mathrm{X}$ and in sample $\mathrm{Y}$ (joint occurrences), $b$ is the number of species in sample $\mathrm{X}$ but not in $\mathrm{Y}$, and $c$ is the number of species in sample $\mathrm{Y}$ that were not collected in sample $\mathrm{X}$. $\mathrm{S}_{\mathrm{J}}$ ranges from 0 (no similarity) to 1 (samples identical).

Cluster analyses using the Numerical Taxonomy and Multivariate Analysis System (Rohlf, 1997) grouped similar sample collections based on information from a similarity 
Table 1. Fish collected by standardized sampling in Gilbert Bay, Labrador during 2004 (unless noted otherwise). $\mathcal{N}=$ total number of fish collected.

\begin{tabular}{|c|c|c|c|c|c|c|c|c|}
\hline \multirow{2}{*}{$\begin{array}{l}\text { Family } \\
\text { Species }\end{array}$} & \multirow[b]{2}{*}{ Common name } & \multirow[b]{2}{*}{$\mathrm{N}$} & \multicolumn{2}{|c|}{ Standard Length $(\mathrm{cm})$} & \multicolumn{4}{|c|}{ Presence at Site 1, 2 or 3} \\
\hline & & & Range & Mean & June & July & August & October \\
\hline \multicolumn{9}{|l|}{ Acipenseridae } \\
\hline Acipenser oxyrinchus oxyrinchus & Atlantic sturgeon* & 1 & & 162 & \multicolumn{4}{|c|}{ Williams Harbour Run in August 2004} \\
\hline \multicolumn{9}{|l|}{ Clupeidae } \\
\hline Clupea harengus & Atlantic herring & 17 & $14.0-34.0$ & 26.5 & 1 & 1 & - & 1 \\
\hline \multicolumn{9}{|l|}{ Salmonidae } \\
\hline Salmo salar & Atlantic salmon & 3 & $21.0-55.3$ & 42.8 & - & 1,3 & 1 & - \\
\hline Salvelinus alpinus & Arctic char & 23 & $3.2-46.5$ & 36 & 1,2 & $1,2,3$ & - & - \\
\hline Salvelinus fontinalis & brook trout & 1 & 5.6 & 5.6 & - & 1 & - & - \\
\hline \multicolumn{9}{|l|}{ Osmeridae } \\
\hline Mallotus villosus & capelin & $5.00 \mathrm{E}+04$ & $10-15.4$ & 14.5 & - & 1,3 & - & - \\
\hline Osmerus mordax & rainbow smelt & 12 & $2.0-4.6$ & 3.3 & - & 3 & 2,3 & 3 \\
\hline \multicolumn{9}{|l|}{ Gadidae } \\
\hline Gadus morhua & Atlantic cod & 73 & $9.8-56.5$ & 36.27 & 2 & $1,2,3$ & $1,2,3$ & $1,2,3$ \\
\hline Gadus ogac & Greenland cod & 291 & $2.0-48.8$ & 15.26 & 1,2 & 1,2 & $1,2,3$ & 1,3 \\
\hline Urophycis tenuis & white hake & 3 & $5.5-11.0$ & 7.8 & - & - & 1 & - \\
\hline \multicolumn{9}{|l|}{ Gasterosteidae } \\
\hline Gasterosteus aculeatus & threespine stickleback & 81 & $1.9-7.2$ & 4.89 & $1,2,3$ & $1,2,3$ & $1,2,3$ & - \\
\hline Gasterosteus wheatlandi & blackspotted stickleback & 9 & $2-5.5$ & 4.43 & 1,2 & - & 1 & - \\
\hline Apeltes quadracus & fourspine stickleback & 2 & $4.5-5.4$ & 4.95 & 1 & - & - & - \\
\hline Pungitius pungitius & ninespine stickleback & 1 & & 4.3 & 1 & - & - & - \\
\hline \multicolumn{9}{|l|}{ Zoarcidae } \\
\hline Zoarces americanus & ocean pout & 35 & $5.1-42.5$ & 23.1 & 1 & 1,3 & 1 & 1,2 \\
\hline \multicolumn{9}{|l|}{ Stichaeidae } \\
\hline Lumpenus maculatus & daubed shanny & 2 & $6.5-11$ & 8.75 & - & 1 & 1 & - \\
\hline \multicolumn{9}{|l|}{ Pholidae } \\
\hline Pholis gunnellus & rock gunnel & 40 & $8.2-24.0$ & 14.21 & $1,2,3$ & $1,2,3$ & 2 & - \\
\hline \multicolumn{9}{|l|}{ Ammodytidae } \\
\hline Ammodytes americanus & American sand lance & $3.50 \mathrm{E}+03$ & $4.2-14.7$ & 8.35 & 1,3 & 1,2 & $1,2,3$ & 1,3 \\
\hline \multicolumn{9}{|l|}{ Scombridae } \\
\hline Scomber scombrus & Atlantic mackerel* & 30 & $28-34$ & 32 & \multicolumn{4}{|c|}{ Williams Harbour Run in August 2005} \\
\hline \multicolumn{9}{|l|}{ Cottidae } \\
\hline Hemitripterus americanus & sea raven & 1 & & 2 & - & 1 & - & - \\
\hline Myoxocephalus scorpius & short horn sculpin & 152 & $1.7-37$ & 13.5 & $1,2,3$ & $1,2,3$ & $1,2,3$ & $1,2,3$ \\
\hline Triglops murrayi & moustache sculpin* & 1 & & 8 & \multicolumn{4}{|c|}{ The Shinneys in August 2004} \\
\hline \multicolumn{9}{|l|}{ Agonidae } \\
\hline Aspidophoroides monopterygius & alligatorfish* & 1 & & 12 & \multicolumn{4}{|c|}{ Winnard Tickle in August 2005} \\
\hline \multicolumn{9}{|l|}{ Cyclopteridae } \\
\hline Cyclopterus lumpus & lumpfish & 62 & $1.1-6.1$ & 2.3 & $1,2,3$ & $1,2,3$ & 2 & 2 \\
\hline \multicolumn{9}{|l|}{ Pleuronectidae } \\
\hline Pseudopleuronectes americanus & winter flounder & 34 & $3.5-33.4$ & 18.41 & 1,3 & $1,2,3$ & $1,2,3$ & - \\
\hline
\end{tabular}

*, collected by non-standard sampling.

matrix (Omori \& Ikeda, 1984). A cluster analysis was also performed to suggest the relationship between the fish assemblage in Gilbert Bay and the assemblage in Trinity Bay determined by using a comparable $10 \mathrm{~m}$ seine (Methven et al., 2001).

\section{RESULTS}

Twenty-one species were collected by standardized sampling at the three sites in Gilbert Bay from June to October 2004 (Table 1). The fish fauna present in the shallow waters (less than $15 \mathrm{~m}$ depth) of Gilbert Bay varied with the oceanographic season.

\section{Seasonal oceanographic conditions within Gilbert Bay}

During the fall of 2003 seawater temperature at Site 1 declined to $0^{\circ} \mathrm{C}$ on 5 December (Figure 2) and then fluctuated near $0^{\circ} \mathrm{C}$ for 26 days. Temperature declined further and remained subzero for 129 days from 31 December 2003 until 8 May 2004 , reaching a minimum of $-1.7^{\circ} \mathrm{C}$. Site 1 was completely covered by landfast ice on 15 January and remained covered for 117 days until 11 May. Site 1 did not warm consistently above $0^{\circ} \mathrm{C}$ until 4 June, ending six months of near zero seawater temperatures.

Figure 3 shows the salinity at each site on 23 August. The near-surface (1 m depth) salinity measured at $20 \mathrm{~m}$ distance 
Table 2. Catch per unit effort (number caught/100 $\mathrm{m}$ towed) for species collected with a $10 \times 1.5 \mathrm{~m}$ seine during the daytime.

\begin{tabular}{|c|c|c|c|c|c|c|c|c|c|c|c|c|}
\hline \multirow{2}{*}{$\begin{array}{l}\text { Family } \\
\text { Species }\end{array}$} & \multicolumn{3}{|c|}{ June } & \multicolumn{3}{|c|}{ July } & \multicolumn{3}{|c|}{ August } & \multicolumn{3}{|c|}{ October } \\
\hline & Site 1 & Site 2 & Site 3 & Site 1 & Site 2 & Site 3 & Site 1 & Site 2 & Site 3 & Site 1 & Site 2 & Site 3 \\
\hline \multicolumn{13}{|l|}{ Salmonidae } \\
\hline Salvelinus fontinalis & 0 & 0 & 0 & 0.1 & 0 & 0 & 0 & 0 & 0 & 0 & 0 & 0 \\
\hline \multicolumn{13}{|l|}{ Osmeridae } \\
\hline Mallotus villosus & 0 & 0 & 0 & 675.4 & 0 & 0 & 0 & 0 & 0 & 0 & 0 & 0 \\
\hline Osmerus mordax & 0 & 0 & 0 & 0 & 0 & 0.5 & 0 & 4.3 & 1.3 & 0 & 0 & 1 \\
\hline \multicolumn{13}{|l|}{ Gadidae } \\
\hline Gadus ogac & 0 & 0 & 0 & 0 & 0 & 0 & 0 & 0 & 0 & 1 & 0 & 0 \\
\hline \multicolumn{13}{|l|}{ Gasterosteidae } \\
\hline Gasterosteus aculeatus & 1.9 & 11.4 & 9.9 & 0.4 & 0.4 & 0.5 & 0.9 & 0.5 & 0.7 & 0 & 0 & 0 \\
\hline Gasterosteus wheatlandi & 0.2 & 0.9 & 0 & 0 & 0 & 0 & 0.4 & 0 & 0 & 0 & 0 & 0 \\
\hline Apeltes quadracus & 0.2 & 0 & 0 & 0 & 0 & 0 & 0 & 0 & 0 & 0 & 0 & 0 \\
\hline \multicolumn{13}{|l|}{ Zoarcidae } \\
\hline Zoarces americanus & 0.2 & 0 & 0 & 0.5 & 0 & 0 & 0 & 0 & 0 & 0 & 2.7 & 0 \\
\hline \multicolumn{13}{|l|}{ Stichaeidae } \\
\hline Lumpenus maculatus & 0 & 0 & 0 & 0.1 & 0 & 0 & 0 & 0 & 0 & 0 & 0 & 0 \\
\hline \multicolumn{13}{|l|}{ Pholidae } \\
\hline Pholis gunnellus & 0.49 & 0.9 & 4 & 1.8 & 0.4 & 1 & 0 & 2.1 & 0 & 0 & 0 & 0 \\
\hline \multicolumn{13}{|l|}{ Ammodytidae } \\
\hline Ammodytes americanus & 2.3 & 0 & 0 & 0.8 & 0 & 0 & 0.4 & 0 & 0 & 2.9 & 0 & 1 \\
\hline \multicolumn{13}{|l|}{ Cottidae } \\
\hline Hemitripterus. americanus & 0 & 0 & 0 & 0.1 & 0 & 0 & 0 & 0 & 0 & 0 & 0 & 0 \\
\hline Myoxocephalus scorpius & 0.3 & 0.9 & 0.7 & 1.6 & 0 & 1 & 0 & 1.1 & 2 & 1.4 & 5.7 & 19 \\
\hline \multicolumn{13}{|l|}{ Cyclopteridae } \\
\hline Cyclopterus lumpus & 1.6 & 6.4 & 1.3 & 0.5 & 1.6 & 0 & 0 & 0.5 & 0 & 0 & 0.9 & 0 \\
\hline \multicolumn{13}{|l|}{ Pleuronectidae } \\
\hline Pseudopleuronectes americanus & 0.6 & 0 & 0 & 1.1 & 0 & 0 & 0 & 0 & 0.7 & 0 & 0 & 0 \\
\hline Total number collected & 47 & 45 & 24 & $5009 *$ & 6 & 6 & 4 & 16 & 7 & 11 & 16 & 21 \\
\hline Species richness & 9 & 5 & 4 & 11 & 3 & 4 & 3 & 5 & 4 & 3 & 3 & 3 \\
\hline
\end{tabular}

*, Capelin catches estimated at 5000 individuals at Site 1 in July.

from the shoreline at Sites 1, 2 and 3 was 28.6\%o, 26.8\%o and $23.9 \%$ respectively. Salinity variation among sites (due to river outflow) was confined to the upper $10 \mathrm{~m}$ of the water column. The salinity at a depth of $12 \mathrm{~m}$ was similar at Sites 1 , 2 and 3 , measuring $30.0 \%$, $29.9 \%$ and $29.9 \%$ respectively (Figure 3). While the near-surface salinity differed at the three sites, the near-surface temperatures were similar. For example on 23 August, seawater temperature at $1 \mathrm{~m}$ depth measured at $20 \mathrm{~m}$ distance from the shoreline at Sites 1, 2 and 3 was $13.2^{\circ} \mathrm{C}, 14.4^{\circ} \mathrm{C}$, and $14.5^{\circ} \mathrm{C}$ respectively.

Vertical structure in seawater temperature and salinity along the main axis of Gilbert Bay is presented in Figure 4. Subsurface water column structure near the mouth of the bay suggests a penetration of water from the Labrador Shelf (Colbourne et al., 2005). Seawater temperature below the seasonal thermocline remains $<0^{\circ} \mathrm{C}$. Waters at the head of the bay near the Gilbert River have reduced salinity.

\section{Seasonality in the occurrence of fish in Gilbert Bay}

Species richness $(\mathbf{S})$ was highest in spring and summer (June $\mathrm{S}=14$, July $\mathrm{S}=17$, August $\mathrm{S}=16$ ) and declined in autumn (October $\mathrm{S}=8$, Table 1). This pattern was consistent among all sites, for all sampling equipment and for day and night collections (10 m seine, Site 1) with mean species richness consistently higher in June, July and August than in comparable collections during October (Tables 2-5). The fish collected fell into the categories suggested by Tyler (1971) for the frequency of occurrence of fish collected by standardized sampling in Passamaquoddy Bay in the Bay of Fundy. There were 'regular' species present on nearly every sampling date, 'periodic' species present only during certain months, and 'occasional' species present in the samples irregularly and in low numbers.

Regular species, collected in each of the four months in this study, include: Gadus morhua Atlantic cod, Gadus ogac Richardson, 1836 Greenland cod, Zoarces americanus (Bloch \& Schneider, 1801) ocean pout, Ammodytes americanus DeKay, 1842 American sand lance, Myoxocephalus scorpius (Linnaeus, 1758) shorthorn sculpin, and Cyclopterus lumpus Linnaeus, 1758 lumpfish. Juvenile and adult sized fish were collected for each regular species (Table 1).

Salvelinus alpinus Arctic char, Salmo salar Atlantic salmon and Mallotus villosus (Müller, 1776) capelin are periodic species collected in Gilbert Bay in June-July, July-August 
Table 3. Catch per unit effort (number caught/100 m towed) for each species using a $10 \times 1.5 \mathrm{~m}$ seine at Site 1 at night.

\begin{tabular}{|c|c|c|c|c|}
\hline $\begin{array}{l}\text { Family } \\
\text { Species }\end{array}$ & June & July & August & October \\
\hline \multicolumn{5}{|l|}{ Salmonidae } \\
\hline Salmo salar & 0 & 0.7 & 0 & 0 \\
\hline Salvelinus alpinus & 0 & 0.7 & 0 & 0 \\
\hline \multicolumn{5}{|l|}{ Gadidae } \\
\hline Gadus ogac & 0 & 0 & 10.9 & 13.6 \\
\hline Urophycis tenuis & 0 & 0 & 0.5 & 0 \\
\hline \multicolumn{5}{|l|}{ Gasterosteidae } \\
\hline Gasterosteus aculeatus & 5.6 & 0 & 1.7 & 0 \\
\hline Gasterosteus wheatlandi & 2.8 & 0 & 0 & 0 \\
\hline Pungitius pungitius & 0.9 & 0 & 0 & 0 \\
\hline \multicolumn{5}{|l|}{ Zoarcidae } \\
\hline Zoarces americanus & 0 & 0 & 3.2 & 1.2 \\
\hline \multicolumn{5}{|l|}{ Stichaeidae } \\
\hline Lumpenus maculatus & 0 & 0 & 0.2 & 0 \\
\hline \multicolumn{5}{|l|}{ Ammodytidae } \\
\hline Ammodytes americanus & 0 & 0 & 153.5 & 1 \\
\hline \multicolumn{5}{|l|}{ Cottidae } \\
\hline Myoxocephalus scorpius & 1.9 & 0 & 2.3 & 2.8 \\
\hline \multicolumn{5}{|l|}{ Pleuronectidae } \\
\hline Pseudopleuronectes americanus & 1.9 & 0.7 & 0.9 & 0 \\
\hline Total number collected & 14 & 3 & $1,129 *$ & 58 \\
\hline Species richness & 5 & 3 & 8 & 4 \\
\hline
\end{tabular}

*, sand lance catch estimated at 1000 individuals at Site 1 in August.

and July respectively. All periodic species were of adult size (Table 1) indicating their occurrence at the time of collection may be related to spawning.

Occasional species include: Salvelinus fontinalis (Mitchill, 1814) brook trout, Urophycis tenuis (Mitchill, 1814) white hake, Gasterosteus wheatlandi Putnam, 1867 blackspotted stickleback, Apeltes quadracus (Mitchill, 1815) fourspine stickleback, Pungitius

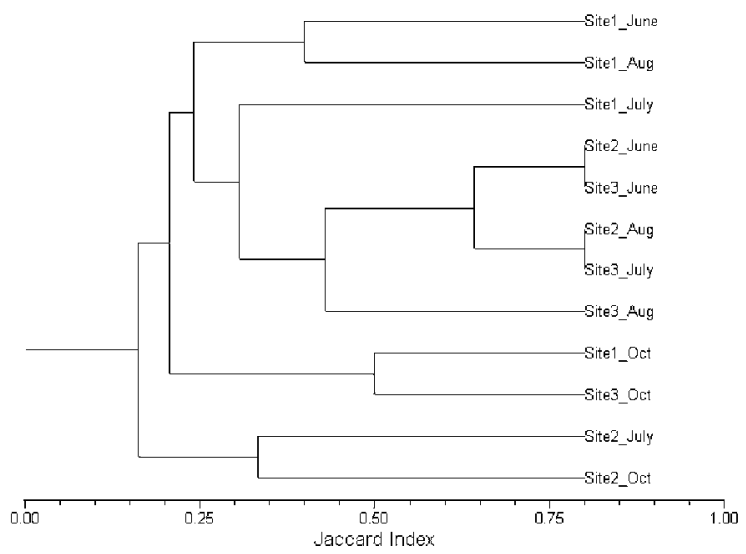

Figure 5. Dendrogram constructed using values of the Jaccard similarity coefficient calculated for daytime fish collections with the $10 \mathrm{~m}$ seine in June, July, August and October 2004 at Sites 1, 2 and 3 .

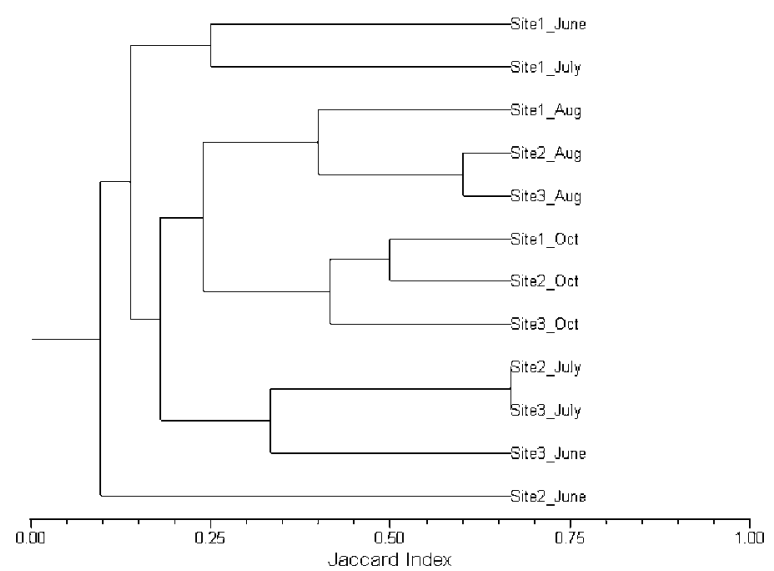

Figure 6. Dendrogram constructed for daytime fish collections with the $25 \mathrm{~m}$ seine in June, July, August and October 2004 at Sites 1,2 and 3 .

pungitius (Linnaeus, 1758) ninespine stickleback, Lumpenus maculatus (Fries, 1837) daubed shanny and Hemitripterus americanus (Gmelin, 1789) sea raven (Table 1).

The remaining five species collected by standardized sampling (Table 1), Pseudopleuronectes americanus (Walbaum, 1792) winter flounder, Pholis gunnellus (Linnaeus, 1758) rock gunnel, Gasterosteus aculeatus Linnaeus, 1758 threespine stickleback, Osmerus mordax (Mitchill, 1814) rainbow smelt and Clupea harengus Linnaeus, 1758 Atlantic herring, are difficult to categorize because each species was collected in three of the four months of sampling. It is uncertain whether these species should be categorized as regular or periodic. Juvenile and adult sized fish were collected for all of these species, except for Osmerus mordax where only juveniles were collected (all less than $46 \mathrm{~mm}$, Table 1).

\section{Distribution of fish within Gilbert Bay}

Ten of the 21 species collected by standardized sampling were present at all three sites during one or more of the four sampling months (Table 1). Species distributed at all three sampling sites included: Salvelinus alpinus, Gadus morhua, Gadus ogac, Gasterosteus aculeatus, Zoarces americanus, Pholis gunnellus, Ammodytes americanus, Myoxocephalus scorpius, Cyclopterus lumpus and Pseudopleuronectes americanus.

Species richness (S) was highest at Site $1(\mathrm{~S}=20)$ and decreased with increasing distance from the ocean to Site $2(\mathrm{~S}=12)$ and Site $3(\mathrm{~S}=13)$. Clupea harengus, Salvelinus fontinalis, Urophycis tenuis, Apeltes quadracus, Pungitius pungitius, Lumpenus maculatus and Hemitripterus americanus were collected only at Site 1. Osmerus mordax was the only species out of 21 collected by standardized sampling not found at Site 1 . There was no species found only at Site 2, or only at Site 3.

\section{Cluster analysis of species assemblages at Sites 1, 2 and 3}

Cluster analyses based on the Jaccard coefficient for the $10 \mathrm{~m}$ seine collections (Table 2 ) show a very weak distinction between Site 1 and Sites 2 and 3 at a very low per cent similarity (Figure 5). Highest similarities occur between Sites 2 and 3 in June (80\%) and Site 2 in August and Site 3 in July $(80 \%)$ (Figure 5). The high similarity in June is due to the 
Table 4. Catch per unit effort (number caught/total number of hauls) for each species using a $25 \times 1.5 \mathrm{~m}$ seine during the daytime.

\begin{tabular}{|c|c|c|c|c|c|c|c|c|c|c|c|c|}
\hline \multirow{2}{*}{$\begin{array}{l}\text { Family } \\
\text { Species }\end{array}$} & \multicolumn{3}{|c|}{ June } & \multicolumn{3}{|c|}{ July } & \multicolumn{3}{|c|}{ August } & \multicolumn{3}{|c|}{ October } \\
\hline & Site 1 & Site 2 & Site 3 & Site 1 & Site 2 & Site 3 & Site 1 & Site 2 & Site 3 & Site 1 & Site 2 & Site 3 \\
\hline \multicolumn{13}{|l|}{ Salmonidae } \\
\hline Salmo salar & 0 & 0 & 0 & 0 & 0 & 0 & 0.333 & 0 & 0 & 0 & 0 & 0 \\
\hline Salvelinus alpinus & 0 & 2 & 0 & 0 & 0 & 0 & 0 & 0 & 0 & 0 & 0 & 0 \\
\hline \multicolumn{13}{|l|}{ Osmeridae } \\
\hline Mallotus villosus & 0 & 0 & 0 & $22,500^{1}$ & 0 & 0 & 0 & 0 & 0 & 0 & 0 & 0 \\
\hline \multicolumn{13}{|l|}{ Gadidae } \\
\hline Gadus spp. & 0 & 0 & 0 & 0 & 0 & 0 & 0 & $0.333^{*}$ & $2.5^{*}$ & 0 & 0 & 0 \\
\hline Gadus morhua & 0 & 0.5 & 0 & 0 & 0 & 0 & 0 & 0 & 0 & 0 & 0 & 0 \\
\hline Gadus ogac & 0 & 3 & 0 & 0 & 0 & 0 & 0.667 & 8.667 & 12.5 & 18 & 0 & 0 \\
\hline \multicolumn{13}{|l|}{ Gasterosteidae } \\
\hline Gasterosteus aculeatus & 0 & 0 & 0.333 & 0 & 0.289 & 0 & 0 & 0 & 0 & 0 & 0 & 0 \\
\hline Gasterosteus wheatlandi & 0.2 & 0 & 0 & 0 & 0 & 0 & 0 & 0 & 0 & 0 & 0 & 0 \\
\hline Apeltes quadracus & 0.2 & 0 & 0 & 0 & 0 & 0 & 0 & 0 & 0 & 0 & 0 & 0 \\
\hline \multicolumn{13}{|l|}{ Pholidae } \\
\hline Pholis gunnellus & 0 & 1 & 0 & 0 & 1 & 0.111 & 0 & 0 & 0 & 0 & 0 & 0 \\
\hline \multicolumn{13}{|l|}{ Ammodytidae } \\
\hline Ammodytes americanus & 8 & 0 & 1 & $500^{2}$ & 0.143 & 0 & $500^{3}$ & 0.667 & 8.5 & 0 & 0 & 2 \\
\hline \multicolumn{13}{|l|}{ Cottidae } \\
\hline Myoxocephalus scorpius & 0 & 0 & 0 & 0 & 1.143 & 0.444 & 0 & 0 & 1.5 & 1.5 & 0.333 & 0.667 \\
\hline \multicolumn{13}{|l|}{ Cyclopteridae } \\
\hline Cyclopterus lumpus & 0 & 0.5 & 0 & 0 & 3.143 & 0.222 & 0 & 0 & 0 & 0 & 0 & 0 \\
\hline \multicolumn{13}{|l|}{ Pleuronectidae } \\
\hline Pseudopleuronectes americanus & 0 & 0 & 0.333 & 0 & 0.714 & 0.111 & 0 & 0.333 & 0 & 0 & 0 & 0 \\
\hline Total number collected & 42 & 14 & 5 & 50,000 & 45 & 8 & 1,503 & 30 & 50 & 39 & 1 & 8 \\
\hline Species richness & 3 & 5 & 3 & 2 & 6 & 4 & 3 & 3 or 4 & 3 or 4 & 2 & 1 & 2 \\
\hline
\end{tabular}

*, either Gadus morhua or G. ogac. Unidentifiable due to mangling during hauling. ', Capelin catch estimated at 40,000 individuals in the first haul and 5,000 individuals in the second haul at Site 1 in July; ${ }^{2}$, sand lance catch estimated at 1000 individuals in the first haul at Site 1 in July; ${ }^{3}$, sand lance catch estimated at 500 individuals in the first haul, 500 individuals in the second haul and 500 individuals in the third haul at Site 1 in August.

presence of Gasterosteus aculeatus, Pholis gunnellus, Myoxocephalus scorpius and Cyclopterus lumpus at both sites (Table 2) with $G$. aculeatus, $P$. gunnellus and $M$. scorpius contributing to the high similarity between Sites 2 and 3 in August and July respectively (Table 2). In general, Site 1 differs from the other two sites by its greater fauna diversity. This is due in large part to the presence of Salvelinus fontinalis, Mallotus villosus, Apeltes quadracus, Lumpenus maculatus and Hemitripterus americanus which were collected with the $10 \mathrm{~m}$ seine only at Site 1 (Table 2).

Species richness declined from $S=10,7,6$ and 3 in June, July, August and October respectively for the $25 \mathrm{~m}$ seine samples (Table 4). Collections made in August at Sites 1, 2 and 3 and collections made in October at Sites 1, 2 and 3 group together in Figure 6. Collections made in July at Sites 2 and 3 are $67 \%$ alike due to co-occurrence of Myoxocephalus scorpius, Cyclopterus lumpus and Pseudopleuronectes americanus. Site 2 in June is $90 \%$ dissimilar from the other sites in species composition (Table 4; Figure 6). Cluster analyses based on the $10 \mathrm{~m}$ seine collections suggest a spatial structure, while the cluster analyses based on the $25 \mathrm{~m}$ seine (which samples deeper water) are more suggestive of a temporal structure.

\section{Comparison of Gilbert Bay with Trinity Bay}

Figure 7 presents a comparison of the fish species caught using the $10 \mathrm{~m}$ beach seine at Site 1 in Gilbert Bay with the fish collected from Bellevue Beach in Trinity Bay by Methven et al. (2001) also using a $10 \mathrm{~m}$ seine during the months of June, July, August and October. Cluster analysis using values of the Jaccard coefficient shows the faunal compositions of the two sites are only $33 \%$ similar. Day-night collections at Site 1 in Gilbert Bay are $47 \%$ similar, while day-night collections at Bellevue Beach in Trinity Bay are 55\% similar. Eleven species collected (either during the day or night) at Site 1 in Gilbert Bay were also present in Trinity Bay: Salvelinus fontinalis, Mallotus villosus, Gadus ogac, Urophycis tenuis, Gasterosteus aculeatus, Gasterosteus wheatlandi, Zoarces americanus, Pholis gunnellus, Myoxocephalus scorpius, Cyclopterus lumpus and Pseudopleuronectes americanus.

Six species collected by the $10 \mathrm{~m}$ beach seine at Site 1 in Gilbert Bay were not present at Bellevue Beach during similar sampling months: Salmo salar, Salvelinus alpinus, Pungitius pungitius, Lumpenus maculatus, Ammodytes americanus and Hemitripterus americanus. Methven et al. (2001) collected eight species in June, July, August and October which 
Table 5. Catch per unit effort (number caught/total hours fished) for each species collected with a 30×3.7 m gillnet.

\begin{tabular}{|c|c|c|c|c|c|c|c|c|c|}
\hline \multirow{2}{*}{$\begin{array}{l}\text { Total hours net was fished } \\
\text { Family }\end{array}$} & \multicolumn{3}{|c|}{ July } & \multicolumn{3}{|c|}{ August } & \multicolumn{3}{|c|}{ October } \\
\hline & Site 1 & Site 2 & Site 3 & Site 1 & Site 2 & Site 3 & Site 1 & Site 2 & Site 3 \\
\hline Species & 88 & 67 & 70 & 74 & 71 & 73 & 45 & 45 & 47 \\
\hline \multicolumn{10}{|l|}{ Clupeidae } \\
\hline Clupea harengus & 0.034 & 0 & 0 & 0 & 0 & 0 & 0.267 & 0 & 0 \\
\hline \multicolumn{10}{|l|}{ Salmonidae } \\
\hline Salmo salar & 0 & 0 & 0.0292 & 0 & 0 & 0 & 0 & 0 & 0 \\
\hline Salvelinus alpinus & 0 & 0.045 & 0.157 & 0 & 0 & 0 & 0 & 0 & 0 \\
\hline \multicolumn{10}{|l|}{ Osmeridae } \\
\hline Mallotus villosus & 0.045 & 0 & 0.157 & 0 & 0 & 0 & 0 & 0 & 0 \\
\hline \multicolumn{10}{|l|}{ Gadidae } \\
\hline Gadus morhua & 0.034 & 0.119 & 0.1 & 0.203 & 0.24 & 0.03 & 0.044 & 0.222 & 0.234 \\
\hline Gadus ogac & 0.307 & 0.015 & 0 & 0.216 & 0.01 & 0 & 0.511 & 0 & 0.043 \\
\hline \multicolumn{10}{|l|}{ Zoarcidae } \\
\hline Zoarces americanus & 0 & 0 & 0.0147 & 0.027 & 0 & 0 & 0 & 0 & 0 \\
\hline \multicolumn{10}{|l|}{ Cottidae } \\
\hline Myoxocephalus scorpius & 0.045 & 0.015 & 0 & 0.257 & 0.03 & 0 & 0.222 & 0 & 0 \\
\hline \multicolumn{10}{|l|}{ Cyclopteridae } \\
\hline Cyclopterus lumpus & 0.01 & 0 & 0 & 0 & 0 & 0 & 0 & 0 & 0 \\
\hline \multicolumn{10}{|l|}{ Pleuronectidae } \\
\hline Pseudopleuronectes americanus & 0 & 0 & 0 & 0.014 & 0 & 0 & 0 & 0 & 0 \\
\hline Total number collected & 42 & 13 & 32 & 53 & 20 & 2 & 46 & 10 & 13 \\
\hline Species richness & 6 & 4 & 5 & 5 & 3 & 1 & 4 & 1 & 2 \\
\hline
\end{tabular}

were not in our $10 \mathrm{~m}$ seine collections from Site 1: Leucoraja erinacea (Mitchill, 1825) little skate, Clupea harengus, Salmo trutta Linnaeus, 1758 brown trout, Osmerus mordax, Gadus morhua, Tautogolabrus adspersus (Walbaum, 1792) cunner, Ulvaria subbifurcata (Storer, 1839) radiated shanny, and Myoxocephalus aenaeus (Mitchill, 1814) grubby.

\section{Additions to the collection by non-standard sampling}

Not all fish species present in Gilbert Bay were collected during the standardized sampling. The number of samples in any survey is governed by logistics. Moreover, each type of sampling equipment has deployment restrictions and is
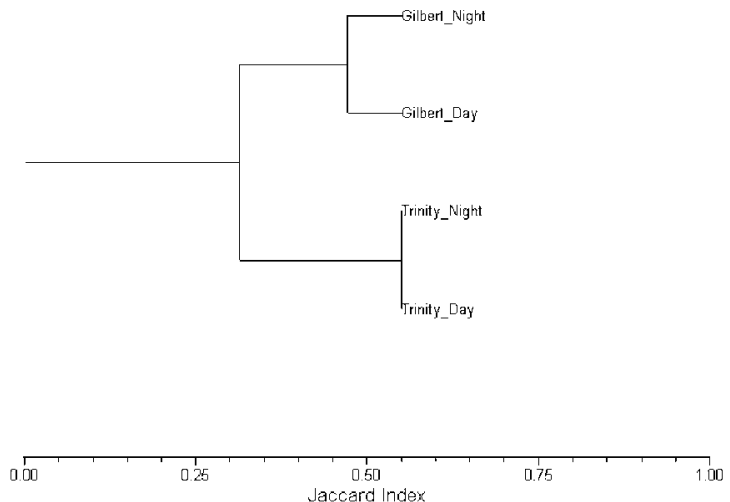

Figure 7. Dendrogram constructed for day and night fish collections with the $10 \mathrm{~m}$ seine at Site 1 in Gilbert Bay, and for comparable data of Methven et al. (2001) for Bellevue Beach in Trinity Bay, Newfoundland. selective for particular species. Four additional species have been collected from Gilbert Bay by non-standard (exploratory) sampling or with the assistance of local fishermen.

Acipenser oxyrinchus oxyrinchus Atlantic sturgeon was caught in non-standard sampling with gill-nets in Williams Harbour Run in August 2004 (Table 1; Figure 1). The sturgeon was released alive after measurement. Triglops murrayi Günther, 1888 moustache sculpin was collected by exploratory sampling with rod and lure in The Shinneys (Table 1; Figure 1). In August 2005 Aspidophoroides monopterygius (Bloch, 1786) alligatorfish was caught by a fisherman in a scallop dredge in the central region of the bay near Winnard Tickle (Table 1; Figure 1) and given to us for preservation. We measured a random sample of Scomber scombrus Linnaeus, 1758 Atlantic mackerel from hundreds caught in a fisherman's gill-net in Williams Harbour Run (Table 1; Figure 1). It is anticipated that other species will be added to the list of fish fauna during scientific monitoring of the MPA.

\section{DISGUSSION \\ Gilbert Bay fish fauna}

Comparison of the Gilbert Bay collection of fish with historical collections for coastal Labrador compiled by Backus (1957) finds 20 species in common. These include: Acipenser oxyrinchus oxyrinchus, Clupea harengus, Salmo salar, Salvelinus alpinus, Salvelinus fontinalis, Mallotus villosus, Osmerus mordax, Gadus morhua, Gadus ogac, Gasterosteus aculeatus, Pungitius pungitius, Zoarces americanus, Pholis gunnellus, Ammodytes americanus, Scomber scombrus, Hemitripterus americanus, Myoxocephalus scorpius, Aspidophoroides monopterygius, Cyclopterus 
lumpus and Pseudopleuronectes americanus. Five species collected in Gilbert Bay are not listed by Backus (1957): Urophycis tenuis, Gasterosteus wheatlandi, Apeltes quadracus, Lumpenus maculatus, and Triglops murrayi.

Methven et al. (2001) collected five marine species in Trinity Bay which we did not find in Gilbert Bay, nor have they been reported for Labrador (Scott \& Scott, 1988; Collette \& Klein-MacPhee, 2002): Leucoraja erinacea, Tautogolabrus adspersus, Ulvaria subbifurcata, Myoxocephalus aenaeus and Myoxocephalus octodecemspinosus (Mitchill, 1814) longhorn sculpin. These five species occur south of the Strait of Belle Isle which is regarded by Steele (1983) as a biogeographic boundary, based on seasonal isotherms of seawater surface temperature. Our collections indicate that the fish fauna of Gilbert Bay is more subarctic than cold-temperate. Fish resident in Gilbert Bay can experience $<0^{\circ} \mathrm{C}$ seawater temperature for six months (December-May) of the year, compared to the three month (January-March) winter season of subzero water temperatures in Trinity Bay, Newfoundland (Methven et al., 2001).

\section{Faunal components in Gilbert Bay}

The three categories based on the frequency of occurrence of a species in standardized sampling (Tyler, 1971) do not fully describe the fish fauna of Gilbert Bay. It may be better to recognize five ecological guilds: (1) fish resident in the bay year-round (these species would appear regularly); (2) anadromous species transiting the bay (species would appear periodically); (3) marine species which migrate into the bay to spawn (species would appear periodically or occasionally); (4) offshore-spawning marine fish for which the bay is a nursery area (species would appear periodically or occasionally); and (5) marine species which migrate into the bay to feed (species would appear occasionally).

\section{Gilbert Bay resident species}

The year-round residency of the Gadus morhua population in Gilbert Bay is well documented (Ruzzante et al., 2000; Green \& Wroblewski, 2000; Morris \& Green, 2002). We collected both juvenile and adult G. morhua, as would be expected for a self-sustaining, local population (Wroblewski et al., 2005). The topographic features of Gilbert Bay promote the retention of pelagic eggs and larvae and the settlement of juveniles within the bay. The archipelago at the mouth of Gilbert Bay (Figure 1) blocks wind-driven water and its plankton from leaving the bay.

Further research is needed to confirm the bay residency of other fish species, but our collections include intertidal zone fish that would find within Gilbert Bay suitable habitat for all life history stages. Pholis gunnellus, Zoarces americanus, Lumpenus maculatus, Gasterosteus aculeatus, Gasterosteus wheatlandi, Apeltes quadracus, and Pungitius pungitius may complete their entire life cycle within the bay. These species are bottom spawners. Their demersal eggs adhere to the bottom substrate or are contained in nests, thus increasing the likelihood of retention of young within the bay.

Myoxocephalus scorpius is apparently a resident of Gilbert Bay, given that adults and juveniles were collected at all three sites during all sampling periods. Adult M. scorpius in October were very colourful with red, orange, yellow and white colours on the lower body and belly. These colours (also reported by Collette \& Klein-MacPhee, 2002) are indicative of spawning, which occurs in NovemberDecember in Newfoundland waters (Ennis, 1970). Eggs are demersal, deposited in shallow water and guarded by males until they hatch. Hatching occurs in March and April in Newfoundland waters (Ennis, 1970). Since ice melt does not occur until mid-May in Gilbert Bay (Figure 2), egg masses of $M$. scorpius in the bay may hatch under the landfast ice.

Gadus ogac is likely a resident of Gilbert Bay. Adults and juveniles were caught during all four months of standardized sampling. Gadus ogac can be caught under the ice during winter (James Russell, Williams Harbour, personal communication). This nearshore species tends to remain in bays and inlets, and is less common along the open coastline.

Pseudopleuronectes americanus may also be a resident of Gilbert Bay. Adult and early juvenile stages of $P$. americanus were collected at all sites except during October. Pseudopleuronectes americanus in Gilbert Bay occur near the edge of the species' range. Backus (1957) records Windy Tickly $\left(52^{\circ} 37^{\prime} \mathrm{N}\right)$, slightly north of Gilbert Bay as the northernmost limit.

Fish resident in Gilbert Bay must endure subzero temperatures for almost half the year (Figures 2\&4). Many of the species we believe are year-round residents of Gilbert Bay produce antifreeze proteins; e.g. Gadus morhua, Gadus ogac, Zoarces americanus, Myoxocephalus scorpius and Pseudopleuronectes americanus (Fletcher et al., 2001).

\section{Gilbert Bay anadromous species}

The management plan of the Gilbert Bay MPA is designed to conserve anadromous species for which there are local subsistence fisheries conducted with gill-nets, i.e. Salmo salar and Salvelinus alpinus. The Salmo salar populations spawning in the rivers of Labrador (Anderson, 1985) are among the few wild populations in North America which have not been impacted genetically by hatchery releases (van Zyll de Jong et al., 2004). Although salmon hatcheries were once operated in Newfoundland, no hatcheries have been built in Labrador (van Zyll de Jong et al., 2004). Local ecological knowledge gained from the aboriginal (Labrador Métis Nation) subsistence fishery for $S$. salar in Gilbert Bay is that migrating salmon enter The Shinneys River (Figure 1) in July. The six metre vertical falls at the mouth of the Gilbert River near the head of Gilbert Bay is a significant barrier to migrating salmon (Anderson, 1985).

Sea-run Salvelinus alpinus usually descend from Labrador lakes and rivers shortly after ice break up, and return in the summer or fall (Anderson, 1985; Scott \& Scott, 1988). Catches during the subsistence fishery for char in Gilbert Bay indicate that S. alpinus leave The Shinneys River in May, feed in the bay, and then return to The Shinneys about mid July (James Russell, Williams Harbour, NL, personal communication). This local knowledge is consistent with our collection of $S$. alpinus (Tables 2-5). Anderson (1985) considers the Gilbert River waterfall a complete barrier to $S$. alpinus.

Anadromous Osmerus mordax aggregate in estuaries and enter rivers in springtime where they deposit adhesive eggs on rocky substrates (Scott \& Crossman, 1973). We collected no adult $O$. mordax $(\sim 120 \mathrm{~cm}$ is the size at maturity; Scott 
\& Scott 1988). However, juvenile 0 . mordax were caught by the $10 \mathrm{~m}$ seine at Site 2 and Site 3, all of which were less than $5 \mathrm{~cm}$ and thus possibly young-of-the-year. Juvenile $O$. mordax were only caught in July, August and October when they were large enough to be retained by the $10 \mathrm{~mm}$ (stretch) mesh netting of the $10 \mathrm{~m}$ seine. Osmerus mordax were not taken in June, which would be closer to the time of hatching.

Andromous Acipenser oxyrinchus oxyrinchus is considered a species of 'special concern' with regard to risk of extinction in Canada (Musick et al., 2000). The A. oxyrinchus oxyrinchus caught (and released) in Williams Harbour Run was likely a young adult (juvenile characteristics are retained up to a total length of $122 \mathrm{~cm}$; Scott \& Scott, 1988). Acipenser oxyrinchus oxyrinchus are not common in coastal waters of southern Labrador, and this individual was caught near the northern limit of the range, reported as Hamilton Inlet, Labrador or possibly Ungava Bay (Scott \& Scott 1988; Collette \& KleinMacPhee, 2002).

\section{Migratory marine species which spawn in Gilbert Bay}

The fish assemblages of the inner and middle bay regions differ somewhat in their composition from the outer portion of Gilbert Bay closest to the Labrador Sea. We include in this faunal component coastal species that migrate considerable distances (10-1000 km or more) to spawn near shore (e.g. Mallotus villosus, Ammodytes americanus and Cyclopterus lumpus).

Capelin Mallotus villosus are smelt-like fish found on the Newfoundland and Labrador Shelf that migrate inshore to spawn on beaches and subtidally at various depths (Templeman, 1948; Nakashima \& Taggart, 2002). During our study the first capelin spawning event in approximately ten years occurred in Gilbert Bay (James Russell, Williams Harbour, personal communication). Capelin were observed spawning on the beach at Site 1 in July where they were collected in the thousands by the $10 \mathrm{~m}$ and $25 \mathrm{~m}$ seines. Capelin were also collected at Site 3 , though only by gillnets and in low numbers. We observed no spawning at Site 3 , even though the beach substrate was suitable (Nakashima \& Taggart, 2002).

We collected $M$. villosus in July only, but capelin have been caught through the ice near Main Tickle (Figure 1) in late March previously (James Russell, Williams Harbour, personal communication). This is supported by Templeman (1948, p. 127) who reports the observation from Alexis Bay during the winter of 1941 when 'men on the outside of Alexis Bay could get white fish or bay caplin as they call them, in the open cracks in the bay ice... in the months of March and April.' Methven et al. (2001) collected M. villosus in winter (March) at Bellevue in Trinity Bay with a $10 \mathrm{~m}$ beach seine. These observations taken together suggest capelin stocks may exist inshore in Newfoundland and Labrador.

In the early 1990s the physical environment of the northwest Atlantic was characterized by prolonged below-normal seawater temperatures and the distribution of $M$. villosus shifted southward from Labrador. Ocean temperatures returned to pre-perturbation values in the late $1990 \mathrm{~s}$, but the behaviour and distribution of $M$. villosus remained unusual (Carscadden et al., 2001). It is therefore noteworthy that we observed spawning capelin in south-eastern Labrador in 2004 .
Little information is available in the literature on the spawning of Ammodytes americanus (Scott \& Scott, 1988; Collette \& Klein-MacPhee, 2002). Our data suggest A. americanus reproduce in Gilbert Bay. Adult $A$. americanus (approximate size at maturity is $9 \mathrm{~cm}$; Collette \& Klein-MacPhee, 2002) were collected in abundance at Site 1 in July (Table 1). Juvenile A. americanus $(5.5-6.7 \mathrm{~cm})$ were collected at Site 1 the following month.

Another coastal species which uses Gilbert Bay as a nursery ground is Cyclopterus lumpus. Adult C. lumpus were caught only near the entrance of Gilbert Bay in non-standard sampling with gill-nets. Small juveniles (1-2 cm SL) were collected at all three sites, consistently at Site 2 during each of the four months sampled. Rockweed (Fucus sp.), a known substrate for juvenile C. lumpus (Collette \& Klein-MacPhee, 2002) occurs at Site 2. Adult C. lumpus apparently spawn near the entrance of Gilbert Bay where boulders and bedrock occur throughout the nearshore shallows. Rocky substrate in shallow waters is the usual habitat for lumpfish spawning. The presence of young-of-the year lumpfish at Site 2 and Site 3 during June, July, August and October suggests spawning is widespread throughout the bay.

\section{Shelf-spawning species for which Gilbert Bay is a nursery area}

We include in this category marine fish which spawn on the continental shelf, but whose pelagic eggs and larvae drift towards the coastline, where the pelagic juveniles settle on inshore nursery grounds. Juvenile Urophycis tenuis were collected in shallow water $(<1 \mathrm{~m})$ at Site 1 . Urophycis tenuis appears to be a shelf-spawning species which uses the coastal zone as a nursery ground throughout much of Atlantic Canada and New England (Collette \& Klein-MacPhee, 2002). The collection at Site 1 in Gilbert Bay represents the northern-most report of juveniles of this species in a shallow coastal habitat. The distribution of $U$. tenuis does not extend north of Lake Melville (Collette \& Klein-MacPhee, 2002).

The coastline of south-eastern Labrador is a nursery ground for Gadus morhua which spawn offshore on Hamilton Bank (Anderson \& Dalley, 1997). With the collapse of cod stocks associated with these offshore banks, it was unknown whether progeny from offshore spawning cod could still be found along the Labrador coast. Individual juvenile $G$. morhua collected during our 2004 field study were genetically analysed to determine population origin (unpublished data of J. Wroblewski and G. Rose, Memorial University and J. Nelson, University of Victoria). The genetic data indicate that not all juvenile G. morhua present in Williams Harbour Run are members of the Gilbert Bay resident population.

\section{Marine species which migrate into Gilbert Bay to feed}

Clupea harengus migrate into Gilbert Bay to feed. We collected C. harengus in gill-nets at Site 1 during June, July and October that averaged $26 \mathrm{~cm} \mathrm{SL}$, with none less than $14 \mathrm{~cm}$. Herring are caught as by-catch in the subsistence fisheries for Salmo salar and Salvelinus alpinus in Gilbert Bay, as early as May when gill-nets are first set after ice melt (James Russell, Williams Harbour, personal communication). There is no local knowledge of herring spawning in the bay.

In late summer of certain years past Scomber scombrus could be caught by fishermen using gill-nets in Williams Harbour 
Run. We observed S. scombrus in Gilbert Bay on 29 August 2005 caught in a fisherman's gill-net. After spawning in the Gulf of St Lawrence, Atlantic mackerel migrate north along the Labrador coast with the seasonal warming of ocean surface waters (Scott \& Scott 1988; Collette \& KleinMacPhee, 2002). In colder years their feeding migration does not extend as far north as Black Island, Labrador at latitude $53^{\circ} 46^{\prime} \mathrm{N}$ (Parsons, 1970).

Historically, Gadus morhua which spawned in early spring on the offshore banks moved in large schools to the coasts of eastern Newfoundland and Labrador, following Mallotus villosus migrating inshore (Rose, 1993). These cod would remain along the coastline during the summer to feed primarily on capelin, and then would migrate back offshore to overwinter and spawn the following spring. With the severe decline in the abundance of cod offshore, large schools of northern cod no longer move along the migration pathways (Rose et al., 2000). However, a 'Sentinel Fishery' for cod established by DFO to monitor traditional inshore fishing grounds provides evidence that cod still migrate to the Labrador coast to feed (Lilly et al., 2004). Identification of population-origin by genetic analysis of adult $G$. morhua caught during the 2004 Sentinel Fishery for cod off Williams Harbour (unpublished data of J. Wroblewski and G. Rose, Memorial University and J. Nelson, University of Victoria) indicates that cod from offshore stocks were present along the headlands of Gilbert Bay. Genetic identification of adult G. morhua we collected during non-standard sampling with gill-nets in 2004 suggests that offshore-spawning cod moved into the outer portion of Gilbert Bay to feed.

\section{Future research}

\section{Biodiversity of fish within the MPA}

Reproductive isolation of the subpopulation of Atlantic cod resident in Gilbert Bay has led to a distinguishable microsatellite nuclear DNA structure (Ruzzante et al., 2000; Beachem et al., 2002). Although as yet unexamined, there exists the possibility of genotypic differentiation in other species resident in Gilbert Bay. Genetic study could clarify the regular, periodic or occasional occurrence of a species in standardized sampling of the bay.

\section{Ocean climate change and Gilbert Bay fish}

The ocean climate of Newfoundland and Labrador has been warming for the past decade (Colborne et al., 2005). Air temperatures over Labrador in January 2004 were $7.5^{\circ} \mathrm{C}$ above normal (standardized to a base period 1971-2000), delaying by one month (from mid-December normally to mid-January in 2004) the formation of landfast ice over Gilbert Bay (Figure 2). This trend is consistent with a global climate change where higher latitudes experience warmer conditions. The MPA established in Gilbert Bay offers researchers a controlled location to study how fish assemblages change in response to ocean climate change. With continued warming of the climate of Gilbert Bay, one would expect the disappearance of some subarctic species and an increasing dominance of cold-temperate fish in the bay's assemblage.

This research was supported by Fisheries and Oceans Canada contracts to Memorial University. Funding was also provided by the 'Coasts Under Stress' (CUS) research project. CUS was funded by the Social Sciences and Humanities Research Council of Canada, and the Natural Sciences and Engineering Research Council of Canada. We thank Corina Russell, James Russell and Wayne Russell for their assistance in the field. John Green, Cliff Russell and Wayne Russell contributed to the collection of fish. Liuming $\mathrm{Hu}$ and Derek Pritchett prepared the figures.

\section{REFERENCES}

Anderson, J.T. \& Dalley, E.L. 1997. Spawning and year-class strength of northern cod (Gadus morhua) as measured by pelagic juvenile cod surveys, 1991-1994. Canadian Fournal of Fisheries and Aquatic Sciences, 54, Supplement 1, 158-167.

Anderson, T.C., 1985. The rivers of Labrador. Canadian Special Publication of Fisheries and Aquatic Sciences, 81, 1-389.

Backus, R.H., 1957. The fishes of Labrador. Bulletin of the American Museum of Natural History, 113, 273-338.

Beachem, T.D., Brattey,J., Miller, K.M., Le, K.D. \& Withler, R.E., 2002. Multiple stock structure of Atlantic cod (Gadus morhua) off Newfoundland and Labrador determined from genetic variation. ICES Journal of Marine Science, 59, 650-665.

Carscadden, J.E., Frank, K.T. \& Leggett, W.C., 2001. Ecosystem changes and the effects on capelin (Mallotus villosus), a major forage species. Canadian Fournal of Fisheries and Aquatic Sciences, 58, 73-85.

Clarke, P.U. \& Fitzhugh, W.W., 1992. Postglacial relative sea level history of the Labrador coast and interpretation of the archaeological record. In Paleoshores lives and prehistory: an investigation on method (ed. L.L. Johnson and M. Strait), pp. 189213. London: CRC Press.

Colbourne, E.B., Fitzpatrick, C., Senciall, D., Stead, P., Bailey, W., Craig, J. \& Bromley, C., 2005. An assessment of the physical oceanographic environment on the Newfoundland and Labrador Shelf during 2004. DFO Canadian Science Advisory Secretariat Science Advisory Report 2005/14.

Collette, B.B. \& Klein-MacPhee, G., 2002. Bigelow and Schroeder's Fishes of the Gulf of Maine, 3rd edn. Washington: Smithsonian Institution Press.

COSEWIG, 2003. COSEWIC assessment and update status report on the Atlantic cod Gadus morhua in Canada. Committee on the Status of Endangered Wildlife in Canada. Ottawa. xi $+76 \mathrm{pp}$.

Ennis, G.P., 1970. Reproduction and associated behaviour in the shorthorn sculpin, Myoxocephalus scorpius in Newfoundland waters. Fournal of the Fisheries Research Board of Canada, 27, 2037-2045.

Fletcher, G.L., Hew, G.L. \& Davies, P.L., 2001. Antifreeze proteins of teleost fishes. Annual Review of Physiology, 63, 359-390.

Gomes, M.C., Haedrich, R.L. \& Villagarcia, M.G., 1995. Spatial and temporal changes in the groundfish assemblages on the Northeast Newfoundland/Labrador Shelf, Northwest Atlantic, 1978-1991. Fisheries Oceanography, 4, 85-101.

Gosse, K.R. \& Wroblewski, J.S., 2004. Variant colorations of Atlantic cod (Gadus morhua) in Newfoundland and Labrador nearshore waters. ICES Journal of Marine Science, 61, 752-759.

Green, J.M. \& Wroblewski, J.S., 2000. Movement patterns of Atlantic cod in Gilbert Bay, Labrador: evidence for bay residency and spawning site fidelity. Fournal of the Marine Biological Association of the United Kingdom, 80, 1077-1085.

Hilborn, R. et al., 2004. When can marine reserves improve fisheries management? Ocean and Coastal Management, 47, 197-205.

Jamieson, G.S. \& Levings, C.O., 2001. Marine protected areas in Canada-implications for both conservation and fisheries management. Canadian Fournal of Fisheries and Aquatic Sciences, 58, 138-156.

Lilly, G.R., Murphy, E.F., Healey, B.P., Maddock Parsons, D. \& Stead, R., 2004. An update on the status of the cod (Gadus morhua) stock in NAFO Divisions 2J+3KL in March 2004. DFO Canadian Scientific Advisory Secretariat Research Document 2004/023. 
Methven, D.A., Haedrich, R.L. \& Rose, G.A., 2001. The fish assemblage of a Newfoundland estuary: diel, monthly, and annual variation. Estuarine, Coastal and Shelf Science, 52, 669-687.

Morris, G.J. \& Green, J.M., 2002. Biological characteristics of a resident population of Atlantic cod (Gadus morhua L.) in southern Labrador. ICES Fournal of Marine Science, 59, 666-678.

Musick, J.A. et al., 2000. Marine, estuarine, and diadromous fish stocks at risk of extinction in North America (exclusive of Pacific salmonids). Fisheries, 25(11), 6-30.

Nakashima, B.S. \& Taggart, C.T., 2002. Is beach-spawning success for capelin, Mallotus villosus (Muller), a function of the beach? ICES Journal of Marine Science, 59, 897-908.

Omori, M. \& Ikeda, T., 1984. Methods in marine zooplankton ecology. New York: Wiley-Interscience, John Wiley \& Sons.

Parsons, L.S., 1970. Northern range extension of the Atlantic mackerel, Scomber scombrus, to Black Island, Labrador. Fournal of the Fisheries Research Board of Canada, 27, 610-613.

Pauley, D., Christensen, V., Guénette, S., Pitcher, T.J., Sumaila, U.R., Walters, C.J., Watson, R. \& Zeller, D., 2002. Towards sustainability in world fisheries. Nature, London, 418, 689-695.

Roberts, C.M. \& Hawkins, J.P., 2000. Fully-protected marine reserves: a guide. WWF Endangered Seas Campaign, 1250 24th Street, NW, Washington, DC 20037, USA and Environment Department, University of York, York, YO10 5DD, UK.

Rohlf, F.J., 1997. NTSYS-pc. Numerical Taxonomy and Multivariate Analysis System. Version 2.00. User Guide. Setauket, NY: Exeter Publishing, Ltd.

Rose, G.A., 1993. Cod spawning on a migration highway in the northwest Atlantic. Nature, London, 366, 2458-2461.

Rose, G.A., deYoung, B., Kulka, D.W., Goddard, S.V. \& Fletcher, G.L., 2000. Distribution shifts and overfishing the northern cod (Gadus morhua): a view from the ocean. Canadian Fournal of Fisheries and Aquatic Sciences, 57, 644-664.

Ruzzante, D.E., Wroblewski, J.S., Taggart, C.T., Smedbol, K., Cook, K. \& Goddard, S.V., 2000. Bay-scale population structure in coastal Atlantic cod in Labrador and Newfoundland, Canada. Journal of Fish Biology, 56, 431-447.
Scott, W.B. \& Crossman, E.J., 1973. Freshwater fishes of Canada. Bulletin. Fisheries Research Board of Canada no. 184, pp. 1-966.

Scott, W.B. \& Scott, M.B., 1988. Atlantic fishes of Canada. Toronto: University of Toronto Press.

Shepard, F.P., 1963. Submarine Geology, 2nd edn. New York: Harper \& Row.

Smedbol, R.K. \& Stephenson, R., 2001. The importance of managing within species diversity in cod and herring fisheries of the north-western Atlantic. Fournal of Fish Biology, 59, Supplement A, 109-128.

Smedbol, R.K. \& Wroblewski, J.S., 2002. Metapopulation theory and northern cod population structure: interdependency of subpopulations in recovery of a groundfish population. Fisheries Research, 55, 161-174.

Steele, D.H., 1983. Marine ecology and zoogeography. In Biogeography and ecology of the island of Nerefoundland (ed. G.R. South), pp. 421-465. The Hague: Dr W. Junk Publishers.

Stonehouse, B., 1989. Polar Ecology. New York: Chapman \& Hall.

Templeman, W., 1948. The life history of the caplin (Mallotus villosus O.F. Muller) in Newfoundland waters. Nerefoundland Department of Natural Resources. Research Bulletin (Fisheries), 17, 1-151.

Tyler, A.V., 1971. Periodic and resident components in communities of Atlantic fishes. Fournal of the Fisheries Research Board of Canada, 28, 935-946.

Worm, B. et al., 2006. Impacts of biodiversity loss on ocean ecosystem services. Science, New York, 314, 787-790.

Wroblewski, J., Neis, B. \& Gosse, K., 2005. Inshore stocks of Atlantic cod are important for rebuilding the East Coast fishery. Coastal Management, 33, 411-432.

Zyll de Jong, M.C. van, Gibson, R.J. \& Cowx, I.G., 2004. Impacts of stocking and introductions on freshwater fisheries of Newfoundland and Labrador, Canada. Fisheries Management and Ecology, 11, 183-193.

Submitted 21 April 2006. Accepted 9 February 2007. 
